\title{
Negation and Modality
}

\section{A Study of Some Epistemic Predicates in Modern Greek}

\author{
Eva Hedin* \\ Stockholm University \\ evahed@ling.su.se
}

\begin{abstract}
This paper deals with the question of negation and mood in Modern Greek verb complementation where there is a choice between an indicative and a subjunctive complement, in particular those with the verb pistévo ( $\pi$ $\sigma \tau \varepsilon v \omega)$ 'think, believe', but

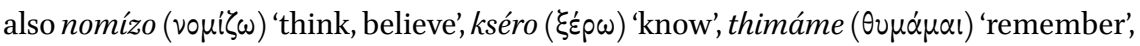

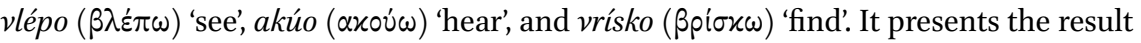
of an empirical study of pistévo, based on an investigation undertaken in the Hellenic National Corpus (HNC) of sentential complements following pistévo. The factor of negation in the matrix is investigated along with two other factors, hypothesized to be of interest, namely first person singular of the present tense in the matrix and second person (singular and plural) in the complement. As was expected, neither any of the three factors individually or any combination of the three can be considered decisive for the choice of mood. What seems to be certain, however, is that the combination of all three constitutes a context that favours the subjunctive and in one case actually seems to exclude an indicative complement, namely when the illocutionary force of the utterance is that of a question, more or less rhetorically eliciting feedback. It thus does not seem to be the presence of the negation, nor any other syntactic factor, that actually triggers the subjunctive with this verb in some contexts, but a particular speech situation (where the three investigated factors are typically present). That is, the prerequisite is not syntactic, but pragmatic.
\end{abstract}

\section{Keywords}

Modern Greek - complementation - mood - negation - polarity - epistemic modality

\footnotetext{
* I would like to thank two anonymous reviewers for comments and suggestions.
} 
There is a group of Modern Greek verbs that, when used in an epistemic sense, may choose either an indicative complement (introduced by the complementizers óti (ó $\tau \iota)$ or pos $\left.(\pi \omega \varsigma)^{1}\right)$ or a subjunctive one (introduced by the subjunctive

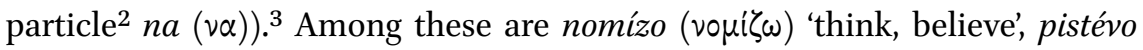

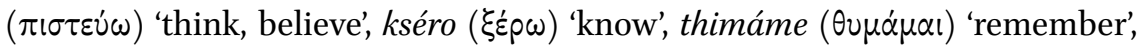

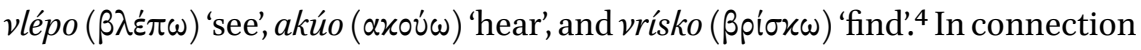
with the question of mood choice with these verbs, reference has often been

1 Óti and pos are more or less synonymous.

2 It has long (since Philippaki-Warburton and Veloudis 1984) been generally assumed in the literature that $n a$ is not a complementizer but a modal marker. The syntactic status of this particle is, however, a debated issue (for further discussion, see, e.g., Roussou 2000 and Giannakidou 2011).

3 It should be noted that the terms indicative and subjunctive are not used to refer to some morphological mood marked on the verb of the complement, but to the modality expressed by the choice of introducer of the complement, óti/pos vs. na. Since the subjunctive is expressed solely by the modal marker $n a$, with epistemic predicates the verb in the complement may well occur in a past tense form such as the aorist, traditionally not associated with the subjunctive.

4 Of interest for the discussion of the paper is when these verbs are used as epistemic predicates. The verb kséro 'know', e.g., may also be used non-epistemically, with obligatory coreference, to express dynamic modality, meaning 'know how, be able' as in (i):
(i) kséro
na fiáxno
pites
know.PRS.ISG SBJV make.IPFV.NPST.ISG pies
'I know how to make pies.'

Something similar goes for thimáme 'remember' which can be used with obligatory coreference, meaning 'remember (to), not forget (to)' as in (ii)-(iii):
(ii) thimáme
na svíno
ta fóta févghondas
remember.PRS.ISG SBJV turn.off.IPFV.NPST.1SG DEF lights leave.GERUND
'I remember to turn off the lights as I'm leaving.'
(iii) thimithika na svíso ta fóta févghondas remember.PFV.PST.1SG SBJV turn-off.PFV.NPST.1SG DEF lights leave.GERUND 'I remembered to turn off the lights as I was leaving.'

In these cases, a subjunctive complement is the only possible choice. See also the comment below (1.1, fn. 6) on the verb nomizo 'think, believe'. 
made to the role of negation. Parallels have also been drawn to the so-called polarity subjunctive exhibited in some Romance languages, where a subjunctive can appear in the complement of certain verbs only in negated or interrogative context (see, e.g., Giannakidou 2011:71 and 1.3 below).

It is a fact that the kind of context typical of a polarity subjunctive sometimes seems to facilitate the choice of a subjunctive complement with some Modern Greek verbs. The verbs referred to above, however, do not behave in the same way in this respect.

\subsection{Nomízo}

It has frequently been noted in the literature that for the verb nomizo 'think, believe' negation is a prerequisite for a subjunctive complement (Kakouriotis 1982: 118; Giannakidou 1995: 100; 2000: 231; Roussou 1996: 273; 1999: 173; 2009: 1814; Holton, Mackridge, and Philippaki-Warburton 1997: 453; Quer 2009: 1785; Siegel 2009: 1871):
(1) nomizo "na érthi / óti tha
think.PRS.1SG SBJV come.PFV.NPST ${ }^{5}$.3SG / COMP FUT
érthi o jánis
come.PFV.NPST.3SG DEF Giannis
'I think that Giannis will come.'
(2) dhen nomizo na érthi / óti tha
NEG think.PRS.1SG SBJV come.PFV.NPST.3SG / COMP FUT
érthi o jánis
come.PFV.NPST.3SG DEF Giannis

'I don't think that Giannis will come.'

This is, to my knowledge, the only example of a Modern Greek epistemic predicate that does not occur with a subjunctive complement without a shift of meaning, unless it is negated. A non-negated nomizo does occur with a subjunctive complement, but then normally with a non-epistemic meaning rather like léo ('say') na 'think' = 'be of the opinion that', 'propose' referring to the future:

5 The abbreviation NPST stands for non-past and is used for the perfective and imperfective non-past forms when combined with the subjunctive and future particles. The imperfective non-past form (IPFV.NPST) is identical to the present form, which is, however, abbreviated PRS. 

(3) eghó nomízo na tin epistrépsis
I think.PRS.1SG SUBJ it.ACC return.PFV.NPST.2SG
'I think you should return it.' ${ }^{\prime}$

\section{$1.2 \quad$ Semi-Factives}

Christidis (1982: 50-51) points out that with the verbs thimáme 'remember' and kséro 'know' subjunctive is obligatory in negated sentences when the verb is in the first person and in the present tense:

\section{(4) dhen thimáme *óti / na ton éxo_sinandísi NEG remember.PRS.1SG COMP / SBJV him meet.PF ${ }^{7}$.1SG 'I don't remember *that I have / to have met him.'}
(5) dhen kséro
*óti / na éxi
tétjes idhées
NEG know.PRS.1SG COMP / SBJV have.IPFV.NPST.3SG such ideas 'I don't know *that he has / him to have such ideas.'

The use of subjunctive in this context is a way to avoid a truth presupposition that would create a contradiction after these semi-factive predicates. By using the modal marker na instead of the complementizer óti, the speaker may explicitly mark the subject's (cf. Siegel 2009: 1874) opinion regarding the truth value of the complement proposition, namely as non-commitment to its truth. The same explanation holds for the semi-factive verbs vlépo 'see' and vrísko 'find' with the meaning 'discover, observe' (also mentioned by Christidis

6 The non-epistemic meaning of (3), repeated here as (i) a), is illustrated by the ungrammaticality of (i) b) where the aorist in the complement rules out the subjunctive. The only possible choice is an óti/pos-complement, as in (ii):

(i) a. eghó nomízo na tin epistrépsis

I think.PRS.1SG SUBJ it.ACC return.PFV.NPST.2SG
b. *eghó nomízo na tin epéstrepses
I think.PRS.1SG SUBJ it.ACC return.PFV.PST.2SG

(ii) eghó nomízo óti/pos tin epéstrepses

I think.PRS.1SG COMP it.ACC return.PFV.PST.2SG

'I think that you returned it.'

7 The perfect and pluperfect periphrases are glossed as PF and PLPF, respectively, also when combined with the subjunctive or future particles. 
1982: $5^{0} \mathrm{fn} \cdot 3^{8}$ ). Also akúo 'hear' could be regarded as semi-factive (when having the meaning 'become aware of').

Since the contradiction that occurs is connected only to the speaker at the time of the utterance, the problem with negation does not normally arise in other persons than the first or other tenses than the present. In these cases there is no need to mark the sentence modally in order to avoid a conflict between the negated predicate and the positive truth presupposition. However, in some contexts, for instance in different kinds of reported speech (more or less explicitly expressed), or when the speaker's earlier thoughts are being referred to, the subjunctive may still be used to avoid a truth presupposition:

(6) dhen thimáte na ton éxi_sinandísi

NEG remember.PRS.3SG SBJV him meet.PF.3SG

'He doesn't remember to have met him.'

(7) dhen kséri na éxi tétjes idhées

NEG know.PRS.3SG SBJV have.IPFV.NPST.3SG such ideas

'He doesn't know him to have such ideas.'

(8) dhen thimómun na ton ixa_sinandísi

NEG remember.IPFV.PST.1SG SBJV him meet.PLPF.1SG

'I didn't remember to have met him.'

(9) dhen íksera na éxi tétjes idhées

NEG know.IPFV.PST.1SG SBJV have.IPFV.NPST.3SG such ideas

'I didn't know him to have such ideas.'

8 Christidis gives the following examples of vlépo and vrísko with subjunctive complements:

(i) dhen vrísko na éxi típota

NEG find.PRS.ISG SBJV have.IPFV.NPST.3SG anything

'I can't find/see that there is anything wrong with him.'

(ii) dhen vlépo na pásxi apó típota

NEG see.PRS.ISG SBJV suffer.IPFV.NPST.3SG from anything

'I can't see that he suffers from anything.'

9 With kséro 'know', when reference is made to one's own earlier thoughts, the non-commitment conveyed does not necessarily belong to some retrospective time. In (i) below the sub- 
In narratives, the choice between óti and na may reveal whose speech or thoughts are being presented, those of the speaker (narrator) or those of the subject. That is, it may tell us if we have to do with direct telling of the narrator, as in (10) below, or with free indirect discourse as in (11):
(10) dhen thimótan
óti ixan_ksanaérthi ekí
NEG remember.IPFV.PST.3SG COMP come-again.PLPF.3PL there
'He didn't remember that they had been there before.'
(11) dhen thimótan na ixan_ksanaérthi ekí
NEG remember.IPFV.PST.3SG SBJV come-again.PLPF.3PL there
'He couldn't remember that they had been there before.'

Likewise, to judge from the following examples with kséro and thimáme, also in a non-negated context a first person predicate may still have a na-complement marking the subject's non-commitment to the truth of the complement:
(12) kséro na ipárxi mia dhiaforá anámesá
know.PRS.1SG SBJV exist.IPFV.NPST.3SG INDF difference between tus
them

'I know there to be a difference between them.' (from Kakouriotis 1982: 125)

(13) eghó thimáme na se ghnórisa stin

I remember.PRS.1SG SBJV you.ACC know.PFV.PST.1SG at.DEF ekdhromi sto ghalaksídhi

excursion to.DEF Galaxidi

'I seem to remember that I got to know you at the excursion to Galaxidi.'

ject (of íksera) reflects on her earlier knowledge (up to that point) but the non-commitment belongs to her present self doing so.

(i) eghó ómos dhen íksera éxi i eklisía mas

I though NEG know.IPFV.PST.1SG SBJV have.IPFV.NPST.3SG DEF church our kamía ajía pu na tin léne mávra, skéftika

any saint who SBJV her call.IPFV.NPST.3PL Maura, think.PFV.PST.1SG

aporiméni

wondering

'Ididn't know that our church had any saint with the name Maura', I thought, wondering. 
Regarding the verb vlépo 'see', Philippaki-Warburton and Veloudis (1984:16o$161 \mathrm{fn} .4$ ) point out that it is perfectly acceptable with a negation in the following example, but not without (cf. also Roussou 1996: 272):

(14) a. dhen idha na kolimbise

NEG see.PFV.PST.1SG SBJV swim.PFV.PST.3SG

'I didn't see that/if he swam.'

b. *ídha na kolímbise

see.PFV.PST.1SG SBJV swim.PFV.PST.3SG

But, as Veloudis (1985: 191) notes, vlépo 'see', thimáme 'remember', akúo 'hear', and kséro 'know' are quite acceptable also in non-negated interrogatives (cf. also Roussou 1996: 273; 1999: 173):10

(15) idhes na kolímbise?

see.PFV.PST.2SG SBJV swim.PFV.PST.3SG

'Did you see that/if he swam?'

(16) thimáse na pérase?

remember.PRS.2SG SBJV pass.PFV.PST.3SG

'Can you remember him passing by?'

(17) ákuses na pandréftike?

hear.PFV.PST.2SG SBJV marry.PFV.PST.3SG

'Have you heard that he should have got married?'

(18) kséris na éfije?

know.PRS.2SG SBJV leave.PFV.PST.3SG

'Do you know that he should have/ if he has left?'

1o Also vrísko, mentioned by Christidis (see fn. 8) can be found in non-negated interrogative context as in (i):

(i) vrískis na mjázun ta eliniká me ta ála find.PRS.2SG SBJV be-similar.IPFV.NPST.3PL DEF Greek with DEF other ghrámata?

letters

'Do you find the Greek letters similar to the others?' 
Also in this interrogative context an óti/pos-complement might give the impression that the speaker considers the content of the complement to be a fact, an interpretation that does not occur with the subjunctive.

That negation or interrogation may not be an absolute prerequisite for the subjunctive with the semi-factive verbs discussed above is indicated by examples like (12) and (13). But it may be more typical in a non-affirmative context that the need occurs to avoid an interpretation of truth presupposition. And this seems to be at least one possible reason for using the subjunctive with these verbs, thereby expressing the subject's non-commitment to the truth of the complement.

\subsection{Pistévo}

The verb pistévo 'think, believe' is sometimes referred to as behaving in a similar way as nomizo 'think, believe' with respect to negation and mood choice. Giannakidou (1994: 58) describes dhen pistévo 'not believe' as an epistemic predicate expressing negative commitment, thus taking a subjunctive complement, whereas the non-negated pistévo is described as a categorical epistemic ${ }^{11}$ governing the indicative (cf. also Giannakidou 1997: 98). In later works she develops the link between mood and negative polarity put forward in Giannakidou 1994, and argues that the subjunctive itself is to be treated as a polarity item (Giannakidou 1995: 99-100). She notes, however, that Modern Greek differs from Romance languages, "where sometimes negation on an indicative verb suffices to trigger subjunctive in the complement" and continues: "a phenomenon interesting in itself, but not really attested in Greek" (Giannakidou 1998: 102). This is also the view of Giannakidou 2000 (the phenomenon is "only marginally attested in Greek") where it is, however, still argued that the subjunctive might be viewed as a polarity item (2000: 231), an argument based on facts like those exemplified in (1)-(2) and (14a-b) above (nomízo and vlépo). Also in Giannakidou 2009, it is stated that the subjunctive may be triggered in certain cases under negation, although the phenomenon is referred to as more marginal than in Romance (2009: $1888 \mathrm{fn}$. 3). In Giannakidou 2011, the following examples with pistévo are given to illustrate the so-called polarity subjunctive:

11 Giannakidou (1994: $5^{8}$ fn. 4) refers to Farkas (1992) who coins the term: "Categorical epistemics are the predicates of belief which express certainty or likelihood with respect to the truth of their argument proposition." 

(19) a. pistévo óti irthe o jánis believe.PRS.1SG COMP come.PFV.PST.3SG DEF John 'I believe that John came.'

b. dhen pistévo óti irthe jánis NEG believe.PRS.1SG COMP come.PFV.PST.3SG DEF John 'I don't believe that John came.'
c. dhen pistévo na irthe o jánis NEG believe.PRS.1SG SBJV come.PFV.PST.3SG DEF John 'I don't expect that John came. (I would hope he didn't).'

It is argued that "the subjunctive can be triggered in the lower clause if the higher verb, which otherwise selects the indicative, is negated" and that this holds for Greek, Romance and Balkan languages ${ }^{12}$ (Giannakidou 2011: 71).

Quer (2009:1785) refers to the subjunctive with dhen pistévo and dhennomizo as "the few cases of negation-licensed subjunctive attested in Greek". He notes, however, that the epistemic predicate may license subjunctive even when it is not negated, giving an example with the negation in the complement (Quer 2009: 1785; cf. Giannakidou and Quer 1997: 108):
(20) pistévo
na $\min$ fiji
norís
believe.PRS.1SG SBJV NEG leave.PFV.NPST.3SG early
'I think (s)he won't leave soon'

This, and even more the fact that pistévo with a subjunctive complement also occurs without a negation at all, makes the description negation-licensed subjunctive less felicitous:

(21) pistévo na éfje
believe.PRS.1SG SBJV leave.PFV.PST.3SG

Lit. 'I believe that he left.' (from Roussou 1996: 276)

(22) pistévo na ákughe

believe.PRS.1SG SBJV hear.IPFV.PST.3SG

Lit. 'I believe that he was hearing.' (from Veloudis 1985: 186)

\footnotetext{
12 For Romance languages Giannakidou refers to Quer (1998; 2001; 2009) and for Balkan languages to Siegel (2009).
} 
(23) pistévo na dhiávases kazandzáki

believe.PRS.1SG SBJV read.PFV.PST.2SG Kazantzakis

Lit. 'I believe that you (have) read Kazantzakis.' (from Philippaki-Warburton 1994: 323)

In the discussions of mood choice with pistévo, reference is also made to person and tense. The question of tense restriction for the matrix verb (not occurring in the aorist or the future) when used with the subjunctive is discussed by Veloudis (1985: 186). He argues that nomizo and pistévo function as some kind of modal verbs and for this reason act in this modal-like manner. Also, Roussou (1996: 276 ; 1999: 173) refers to a restricted tense pattern with epistemic predicates that take a subjunctive complement, claiming that the matrix verb has to be in the present tense. Giannakidou and Quer (1997: 106-107) argue that "pistévo loses its modal properties (specifically, the ability to select a subjunctive complement)" when inflected for tenses other than the present, or for persons other than the first singular. Note the following examples from Quer (2009: 1785):

(24) a. dhen pistévo na éfje norís

NEG believe.PRS.ISG SBJV leave.PFV.PST.3SG early

'I don't think (s)he left early.'

b. *dhen pistévis na éfje norís

NEG believe.PRS.2SG SBJV leave.PFV.PST.3SG early

'You don't think (s)he left early'

c. *dhen pístepsa na éfje norís
NEG believe.PFV.PST.1SG SBJV leave.PFV.PST.3SG early
'I didn't think (s)he left early.'

However, the sensitivity to tense referred to seems rather to be a question of aspect. It does not occur in the perfective past tense aorist, as in the example $(24 \mathrm{c})$ above. But occurrences in the imperfective past tense (Greek:paratatikos) show that the matrix verb is not restricted to the present tense (examples from the HNC corpus): 

(25) a. dhen písteva na pári to lógho o NEG believe.IPFV.PST.1SG SBJV take.PFV.NPST.3SG DEF word DEF sinádhelfos tu pasók colleague DEF.GEN PASOK 'I didn't think my colleague in the PASOK would take the floor.'

b. dhen písteva na ipárxi ke dhéftero NEG believe.IPFV.PST.ISG SBJV exist.IPFV.NPST.3SG also second ston kósmo in.DEF world 'I didn't think there existed another one in the world.'

c. dhen písteva na íxa_kámi os tóte polá NEG believe.IPFV.PST.1SG SBJV do.PLPF.1SG until then many krímata sins 'I didn't think I had made so many sins up to then.'

As for person, it is a fact that the matrix verb pistévo with a subjunctive complement mainly occurs in the first person singular (see 4.2 below for details). That it is not ungrammatical in the plural, however, or in another person, is illustrated by the following examples:

(26) a. dhen pistévume na ksexásate ta katorthómatá NEG believe.PRS.1PL SBJV forget.PFV.PST.2PL DEF deeds mas sto oáka our at.DEF OAKA

'We don't believe you've forgotten our deeds at the Olympic Stadium of Athens!'

b. ávrio éxo páli randevú, an_ke ap_óti tomorrow have.PRS.ISG again appointment although from_what mu ípe dhen pistévi na éxun_aláksi me tell.PFV.PST.3SG NEG believe.PRS.3SG SBJV change.PF.3PL polí ta prághmata much DEF things

'Tomorrow I have another appointment, although from what he told me he doesn't think that things have changed so much.' 
The following example illustrates that another person than first combined with past tense is also acceptable:
(27) dhen pisteve na íxe próvlima me NEG believe.IPFV.PST.3SG SBJV have.IPFV.PST.3SG problem with to xrimatikó_posó ítan sxetiká mikró DEF sum-of-money be.IPFV.PST.3SG rather small 'He didn't think he had a problem with the sum of money. It was rather small.'

\section{$3 \quad$ Meaning Shift}

It has been argued that with the use of a subjunctive complement with pistévo follows a semantic shift of the main verb. According to Giannakidou (2011: 71) dhen pistévo na in example (19 c) above "loses its epistemic meaning and means rather something akin to 'I hope not."' Philippaki-Warburton argues that the subjunctive presents the embedded phrase "more as wish than opinion" (1994: 323; cf. also Holton, Mackridge, and Philippaki-Warburton 1997: 452).

It is true that the subjunctive complement is often used to convey a hopeful assumption. But I would like to argue that it is the assumption (a form of noncommitment to the truth of the complement) that is crucial, whereas the hope may be there or not (cf. section 5 below on similar use of the Scandinavian modal particle $v a ̈ l / v e l)$. The following sentence is scarcely meant to convey that the speaker hopes that the new government will not be able to finish what they have undertaken in time:

(28) se dhío mínes pándos dhen pistévo na

in two months anyway NEG believe.PRS.1SG SBJV

oloklirónonde óla ósa anélave $i$ néa

be.finished.IPFV.NPST.3PL all that undertake.PFV.PST.3SG DEF new

kivérnisi

government

'In any case, I doubt that all that the new government has undertaken can be finished in two months.' 


\section{A Corpus Investigation of pistévo-Complements}

Joseph and Philippaki-Warburton (1987:181-182) argue that a $n a$-complement is much more natural than an óti-complement with pistévo when the sentence is negated. That a $n a$-complement is the more natural alternative in a negated context is illustrated by the following examples:
(29) a. ?dhen pistévo
oti tha fíjis
NEG believe.PRS.1SG COMP FUT leave.PFV.NPST.2SG
b. dhen pistévo
na fijis
NEG believe.PRS.1SG SBJV leave.PFV.NPST.2SG
Lit. 'I don't believe that you will leave.'

The negated example (b) is considered to be more natural than (a) which, admittedly, is a bit hard to interpret taken out of context. But what is actually illustrated by this? The fact that a $n a$-clause is taken as more natural than an óti-clause in this specific example does not necessarily have to be due to the negation. If the negation is kept intact and instead the person of the complement is exchanged, the result of the comparison will change considerably:
(30) a. dhen pistévo
óti tha fighun
NEG believe.PRS.1SG COMP FUT leave.PFV.NPST.3PL
b. dhen pistévo na fighun
NEG believe.PRS.1SG SBJV leave.PFV.NPST.3PL
Lit. 'I don't believe that they will leave.'

There is hardly any need to question example (30a).

If a na-complement were the most natural choice for pistévo in a negated sentence, one would expect that it would be more frequent than the other complement types (with óti/pos) in that kind of context, which is not the case (see 4.1). So what is it that seems to make the subjunctive more "natural" in this sentence and others like it? Are there other contextual factors that may favour or even trigger the subjunctive? This question was the point of departure for an investigation in the Hellenic National Corpus (HNC) of pistévo-complements, undertaken in order to acquire some empirical data of contextual factors that might be of interest for the choice of mood with this predicate. Apart from negation, two other factors were examined (both being present in the typical example above and possibly of interest), namely, the occurrence of the matrix verb in the first person singular of the present tense and the occurrence of the verb in the complement in the second person. 
TABLE 1 Distribution of the complement types

\section{Complement type Occurrences \% occurrences}

\begin{tabular}{lrr}
\hline Óti & 13554 & 89 \\
Pos & 1463 & 10 \\
$N a$ & 150 & 1 \\
Total & 15167 & \\
\hline
\end{tabular}

TABLE 2 Negated pistévo-lemma

Complement type Occurrences \% of occurrences \% of complement type

\begin{tabular}{lrrr}
\hline Óti & 694 & 80 & 5 \\
Pos & 99 & 11 & 7 \\
$N a$ & 75 & 9 & 50 \\
Total & 868 & & \\
\hline
\end{tabular}

\subsection{Negation}

A search in the corpus for the verb pistévo in all its forms immediately followed by óti, pos, or $n a$ gave the following numbers of relevant hits, respectively: 13554,1463 , and 150 (see table 1). That is, $n a$ occurs in approximately $1 \%$ of the complement clauses found.

There were in all 868 sentences that contained a negated pistévo followed by a sentential complement (see table 2). The distribution of the three complement types was the following: 694 complements were introduced by óti, 99 by pos, and 75 by $n a$ (that is, óti and pos represent together more than $90 \%$ ), which, not unexpectedly, demonstrates that $n a$ is totally less frequent after a negated pistévo in the matrix clause than óti and pos. In other words, as was mentioned above, the na-complement cannot be triggered by the negation in the narrow sense of the term. On the other hand, $50 \%$ of the $n a$-complements occur in a negated context which should be compared to approximately 5 and $7 \%$, respectively, for the complements introduced by óti and pos. However, the $50 \%$ in non-negated context show that the negation is far from being a prerequisite for a subjunctive complement after pistévo. In other words, it does not seem to be a question of licensing either. The overall picture of these data is that negation in itself does not seem to be crucial to the choice of a subjunctive clause after pistévo. 
Complement type Occurrences \% of occurrences \% of complement type

\begin{tabular}{lrrr}
\hline Óti & 5454 & 91 & 40 \\
$P o s$ & 420 & 7 & 29 \\
$N a$ & 134 & 2 & 89 \\
Total & 6008 & & \\
\hline
\end{tabular}

TABLE $4 \quad$ Negated pistévo-Present $1 s g$

Complement type Occurrences \% of occurrences \% of complement type (Pistévo Present 1 sg)

\begin{tabular}{lrrr}
\hline Óti & 331 & 77 & 6 \\
Pos & 31 & 7 & 7 \\
$N a$ & 68 & 16 & 51 \\
Total & 430 & &
\end{tabular}

\subsection{Present First Person Singular in the Matrix}

A second search of pistévo in the corpus (in the same context but in word form instead of lemma ${ }^{13}$ ) demonstrated that the $n a$-complements in a great majority of the cases occurred after a matrix clause with the predicate in the first person singular of the present tense. Of the 150 occurrences of $n a$-clauses, $134(89 \%)$ were of this kind (compared to 40 and $29 \%$, respectively, for ót $i$ and pos complements). However, also in this context the $n a$-complements were totally in minority, $98 \%$ of the complements following either óti or pos (see table 3).

Considering negation, a similar picture emerges as from the lemma search. There were 430 negated occurrences of pistévo in the present 1sg, 331 followed by óti, 31 by pos, and 68 by a $n a$-clause (see table 4 ). That is, only in approximately $16 \%$ of the negated sentences was the complement a $n a$-clause. On the other hand, also in this case a large part of the $n a$-complement occurred in negated context ( $51 \%$ to be compared with 6 and $7 \%$, respectively, for óti- and pos-complements).

\footnotetext{
13 Only relevant occurrences of the word form were counted.
} 
According to these data, neither the negation of the matrix predicate nor its occurrence in the first person singular in the present tense, or the combination of both, seems to be decisive for the choice of a $n a$-complement. In the majority of the cases, we find some other complement type. Relative to the other complement types, however, a greater percentage of the $n a$-complements occur in this kind of context.

\subsection{Second Person in the Complement}

The third factor investigated was the occurrence of second person in the complement. As table 5 illustrates, 324 sentences in the material were of this type. The complement types were distributed as follows: in 256 of the cases the subordinate clause was introduced by óti, 16 were pos-clauses, and $5^{2} n a-$

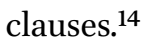

Interestingly, if number in the complement is taken into account and the occurrences in the singular are considered, the difference changes considerably, the number of indicative complements decreasing to 25 (see table 6).

1448 of the sentences found in the corpus with second person in an indicative complement (44 with óti, 4 with pos) were of the kind exemplified in (i) and (ii) below. Second person here has the meaning of 'one' and these occurrences have not been considered relevant for the study:

(i) $i$ zília se káni na min amfivális poté DEF jealousy you.ACC make.PRS.3SG SUBJV NEG doubt.IPFV.NPST.2SG ever óti éxis ádhiko, pistévis óti éxis pánda dhíkio COMP have.PRS.2SG wrong believe.PRS.2SG COMP have.PRS.2SG always right 'Jealousy makes you never to be in doubt whether you might be wrong, you believe you are always right.'

(ii) pistévo pos borís na petíchis me lígha believe.PRS.1SG COMP be.able.PRS.2SG SBJV succeed.PFV.NPST.2SG with few mésa éna kaló apotélesma éxondas tus sostús sinerghátes means INDF good result have.GERUND DEF right companions 'I think you can manage a good result with few means having the right companions.'

A frequent context for second person in an indicative complement is when pistévo in the matrix is also in the second person, e.g. in questions like the following:

(iii) pistévis óti éxis stil? believe.PRS.2SG COMP have.PRS.2SG style 'Do you think that you have style?' 
TABLE 5 Pistévo lemma-second person in the complement

Complement type Occurrences \% of occurrences \% of complement type

\begin{tabular}{lrrr}
\hline Óti & 256 & 79 & 2 \\
$P o s$ & 16 & 5 & 1 \\
$N a$ & 52 & 16 & 35 \\
Total & 324 & & \\
\hline
\end{tabular}

TABLE 6 Pistévo lemma-second person singular in the complement

Complement type Occurrences \% of occurrences \% of complement type

\begin{tabular}{lrcc}
\hline Óti & 20 & 44 & 0,1 \\
$P o s$ & 5 & 11 & 0,3 \\
$N a$ & 20 & 44 & 13 \\
Total & 45 & & \\
\hline
\end{tabular}

To sum up: the mere occurrence of any of the factors studied does not seem to be decisive for the choice of mood. All of them, however, seem to occur more frequently in the subjunctive complements found than in the complements introduced by óti or pos.

\subsection{Relative Influence of the Investigated Factors-Single and in Combination}

In many cases, two or three of the factors discussed occur together. Therefore, in order to examine their relative influence every factor was also considered individually. Consider table 7 .

(iv) kánondas énan apologhismó, pistévete pos ferthíkate do.GERUND INDF account believe.PRS.2PL COMP behave.PFV.PST.2PL sto taléndo sas ópos tu áksize? to.DEF talent your as it.GEN deserve.IPFV.PST.3SG

'Summing up, do you think that you have behaved towards your talent as it deserved?'

70 of the 256 occurrences with ót $i$ and 3 of the 16 with pos were of this kind. 


\begin{tabular}{lccc}
\hline & $\begin{array}{c}\text { Indicative } \\
(\% \text { of } \mathbf{1 5 0 1 7})\end{array}$ & $\begin{array}{c}\text { Subjunctive } \\
\left(\% \text { of } \mathbf{1 5}^{* *}\right)\end{array}$ & $\begin{array}{c}\text { Total } \\
(\% \text { ind/subj })\end{array}$ \\
\hline Negation & $427(3 \%)$ & $5(3 \%)$ & $432(99 / 1 \%)$ \\
1 sg Present in matrix & $5391(36 \%)$ & $45(30 \%)$ & $5436(99 / 1 \%)$ \\
2p in complement & $134(1 \%)$ & 0 & $134(100 / 0 \%)$ \\
(2p sg in complement) & $(22(0,1 \%))$ & $(0)$ & $(22(100 / 0 \%))$ \\
\hline
\end{tabular}

${ }^{*} 15017$ is the total number of occurrences with an indicative complement (cf. table 1 ).

**150 is the total number of occurrences with a subjunctive complement (cf. table 1 ).

When other contextual factors are eliminated, a negated pistévo with a subjunctive complement occurs only in 5 sentences, that is, in approximately $3 \%$ of all the subjunctive clauses (which should be compared to $50 \%$; cf. table 2 ). This means that, if not combined with any of the other factors discussed, negation does not seem to be particularly typical of the na-complements. Also, when considered separately, the occurrence of the matrix verb in the first person singular of the present tense is not more frequent with the subjunctive. Only $30 \%$ of the subjunctive clauses then had 1sg present in the matrix (instead of $89 \%$; cf. table 3). Finally, when the other factors were eliminated, there were no occurrences of na-complements with second person (which should be compared to $35 \%$; cf. table 5). With óti/pos there were 134 sentences of this kind, the great majority of them in the plural.

The great difference between the indicative and subjunctive complements occurs in the combination of the factors examined. Consider table 8.

Negation in combination with 1sg present in the matrix clause occurs in 39 sentences with a $n a$-complement, that is, in $26 \%$ of all the sentences of this kind. This should be compared to 349 sentences with óti/pos, which covers only $2 \%$. Also the combination of 1 sg present in the matrix and second person in the complement without a negation is far more typical for a sentence with a subjunctive complement ( $14 \%$ of the $n a$-clauses compared to approximately $1 \%$ of the indicative clauses). When all the three factors occur together a $n a-$ complement seems to be the most frequent choice. With this combination the subjunctive clauses actually outnumber the óti/pos-complements. In $69 \%$ of all the occurrences with this combination the complement is introduced by na. If, finally, number in the complement is considered, the numerical victory 


\begin{tabular}{|c|c|c|c|}
\hline & $\begin{array}{c}\text { Indicative } \\
(\% \text { of } 15017)\end{array}$ & $\begin{array}{c}\text { Subjunctive } \\
(\% \text { of 150) }\end{array}$ & $\begin{array}{c}\text { Total } \\
\text { (\% ind/subj) }\end{array}$ \\
\hline $\mathrm{Neg}+1$ sg Pres & $349(2 \%)$ & $39(26 \%)$ & $388(90 / 10 \%)$ \\
\hline $\mathrm{Neg}+2 \mathrm{p}$ & $4(0,03 \%)$ & $2(1 \%)$ & $6(67 / 33 \%)$ \\
\hline $\mathrm{Neg}+2 \mathrm{p}$ sing. & o & o & 0 \\
\hline $1 s g$ Pres $+2 p$ & $121(1 \%)$ & $21(14 \%)$ & $142(85 / 15 \%)$ \\
\hline (1sg Pres + 2sg) & $(3(0,02 \%))$ & $(5(3 \%))$ & $(8(37,5 / 62,5 \%))$ \\
\hline $\mathrm{Neg}+1 \mathrm{sg}$ Pres $+2 \mathrm{p}$ & $13(0,09 \%)$ & $29(19 \%)$ & $42(31 / 69 \%)$ \\
\hline$(\mathrm{Neg}+1 \mathrm{sg}$ Pres $+2 s g)$ & (o) & $(15)$ & $(15(0 / 100 \%))$ \\
\hline
\end{tabular}

is complete, since no sentence with all the three factors referred to above, including singular in the complement, was found with an óti/pos-complement, but 15 with a na-clause. The dominance of the subjunctive in this combination of person and number occurs also in non-negated context (although there are few examples of this in the investigated material).

Although this investigation is far from exhaustive, it seems to demonstrate that none of the three factors discussed seems to be able on its own to trigger the subjunctive or even favour it. What seems to be certain, however, is that if all three are at hand (negation together with first person singular in the present tense in the matrix clause combined with second person in the subordinate clause), the choice of an óti-complement is rare, especially if the predicate of the complement is in the singular. This is neatly illustrated by Joseph and Philippaki-Warburton's example (29) repeated as (31) below:

(31) a. ?dhen pistévo óti tha fíjis
NEG believe.PRS.1SG COMP FUT leave.PFV.NPST.2SG

b. dhen pistévo na fíjis

NEG believe.PRS.1SG SBJV leave.PFV.NPST.2SG

Lit. 'I don't believe that you will leave.'

However, that the contextual combination exemplified in a) does not occur in the investigated material does not mean that it would be impossible. Consider example (32): 

(32) a. dhen pistévo óti tha éxis próvlima
NEG believe.PRS.1SG COMP FUT have.IPFV.NPST.2SG problem
b. dhen pistévo na éxis próvlima
NEG believe.PRS.1SG SUBJV have.IPFV.NPST.2SG problem
Lit. 'I don't believe that you will have a problem.'

In this case, it is easier to find an interpretation for sentence a) with the óticomplement, since the verb expresses something independent of the will of the addressee. Consequently, the two sentences seem equally natural without a context, however differently marked for modality (expressing different degrees of commitment to the content of the complement).

\section{$5 \quad$ A “Compulsory" Use of Subjunctive with pistévo?}

In the investigated material 29 of a total of $150 \mathrm{na}$-complements were of the kind that combined the three factors discussed in the previous section. Consider example (33):
(33) dhen pistévo
na 'se
kumúna?
NEG believe.PRS.1SG SUBJV be.IPFV.NPST.2SG communist
Lit. 'I don't believe that you are a communist.'
'You are not a communist, are you?'
'I hope you are not a communist?'

Of the 29 examples found with the combination in question as many as 11 were marked like this, by a question mark. Also, when read out, the intonation signals a particular kind of question. The function of the utterance does not seem to be to make a simple statement, but to seek confirmation of an assumption by posing a question (more or less rhetorical, depending on the context). The question concerns the content of the complement. It seems to function rather like a tag question of the kind exemplified in the English translation of the example above: are you? Questions of this kind may also be followed by a more explicit feedback elicitor like $e$ (see example (42) below) or étsi (lit. 'so'):

(34) dhen pistévo na me apatás me túti NEG believe.PRS.1SG SUBJV me deceive.IPFV.NPST.2SG with this.FEM edhó, étsi?

here so

'(I hope) you are not deceiving me with this woman here, are you?' 
Given that the basic function of a tensed $n a$-complement is to express some kind of non-commitment to its content, it is rather natural that it would be used (with or without negation) when a speaker utters something that needs confirmation from the addressee.

This pragmatic function of pistévo with the subjunctive is very similar to the one exhibited by the modal particle väl/vel in Scandinavian languages. Swedish $v \ddot{a} l$ may serve as an example. Basically having the function of expressing assumption, it often serves as a feedback elicitor. The assumption may, but need not be a hopeful one (cf. section 3 on meaning shift):

$$
\begin{aligned}
& \text { Han har väl stövlar. } \\
& \text { he have.PRS.3SG MODAL.PART boots }
\end{aligned}
$$

a) 'I suppose he has got boots.'

b) 'I suppose/hope he has got boots? He has got boots, hasn't he?'

In one example from the corpus the function of the utterance as a question is explicitly expressed:

(36) dhen pistévo na mu arnithís ke símera?

NEG believe.PRS.1SG SUBJV me deny.PFV.NPST.2SG also today

rótise stréfondas pros ti jinéka tu

ask.PFV.PST.3SG turn.GERUND toward DEF woman his

Lit. 'I don't believe that you will deny me again today, he asked turning toward his wife.'

'You won't deny me again today, will you? he asked turning toward his wife.'

As it seems, in this particular pragmatic function pistévo cannot have anything but a na-complement.

Although this pragmatic context seems to typically occur with the second person (referring to the addressee) in the complement, it does not exclude other persons (the question still being posed to the addressee), as demonstrated in (37) and (38) both from the HNC:

(37) dhen pistévo na ksexásame kanénan?
NEG believe.PRS.1SG SUBJV forget.PFV.PST.1PL anyone
'I don't believe we've (I hope we haven't) forgotten anyone?' 
(38) dhen pistévo na tus ipe jános NEG believe.PRS.1SG SUBJV them say.PFV.PST.3SG DEF Giannos papandoníu óti ...?

Papantoniou COMP

'I don't suppose Giannos Papantoniou told them that ...?'

A question that arises is if it not possible to use a na-complement in a non-negated question with a similar function. As a matter of fact, a couple of examples in the corpus (from the 21 non-negated with this combination of person in matrix and complement) point in this direction:

(39) pistévo na 'se

efxaristiménos. paneftixís,

believe.PRS.1SG SUBJV be.IPFV.NPST.2SG content very.happy

mamá, apándise o santiágo.

mother answer.PFV.PST.3SG DEF Santiago

'I suppose/hope you are happy.' 'Very happy, mother, Santiago answered.'15

(40) pistévo na éxis arketó xróno sti

believe.PRS.1SG SUBJV have.IPFV.NPST.2SG enough time at.DEF

diáthesí su ...

disposal your

'I hope you have enough time at your disposal ...'

In (39) the utterance is not explicitly marked as a question but the addressee's answer to the utterance has the form of a confirmation of a supposition rather than a reaction to a statement. In (40) there is no answer. But also in this case a relevant answer would be 'I have time', 'I am not in a hurry', or something similar, providing confirmation of the hopeful assumption expressed in the preceding utterance.

No non-negated examples of the kind discussed above were found with a question mark in the HNC corpus. A search in Google, however, gives for instance the following examples of this:

(41) bótes pistévo na éxis?

boots think.PRS.1SG SUBJV have.IPFV.NPST.2SG

'I suppose / hope you've got boots?'

15 It should be noted that the text is taken from a translation of a novel by the PeruvianSpanish writer Mario Vargas Llosa. 
(42) dhískoles $i$ epoxés ómos, opóte me éna 15ári ekastós ja difficult DEF times however so with one 15_evro each for óli méra pistévo na íne kalítera ... whole day believe.PRS.1SG SUBJV be.IPFV.NPST.3SG better $e$ ?!

DISCOURSE.PRT

(...) enoíte pos 15 evró ti méra akúghonde polí kalítera of-course COMP 15 evro DEF day sound.PRS.3PL much better apó 50 ... than $5^{0}$ 'Times are hard, though, so 15 euro each for the whole day is better ... isn't it?'

'(...) of course 15 euro a day sounds much better than 50 ...'

However, the fact that in the investigated material all sentences explicitly marked for question were negated, may suggest that this particular pragmatic function is more frequent with negation.

Interestingly, the kind of tag question discussed above is the only type of question that occurred in the material with a $n a$-complement. There were no occurrences of interrogative sentences of the kind Pistévis na éfje? 'Do you think he (might have) left?' The non-negated $n a$-complements all occurred in affirmative context and the interrogative sentences that did occur all had an óti- or pos-complement. This seems to suggest that also interrogation, the other factor mentioned above as associated with polarity, must be considered not to have an impact on the choice of complement type with pistévo.

\section{Summary}

For none of the verbs discussed in this paper does negation actually trigger subjunctive in the complement. Most of them, however, seem to typically occur with the subjunctive in non-affirmative context. Nomizo 'think, believe' is the only verb that takes a subjunctive complement only when negated (when used in the epistemic sense). The semi-factive verbs kséro 'know', thimáme 'remember', vlépo 'see', vrísko 'find,' and akúo 'hear' occur with a subjunctive complement in interrogative as well as negative context. There are examples with semi-factives also in affirmative context, but they don't seem to represent the typical usage. A reason for this limitation to non-affirmative context may be that an undesired interpretation of truth-presupposition (that sometimes occur with these semi-factive verbs, unless the subjunctive is used) may not 
occur as typically in assertive context. Pistévo, finally, differs from the rest by taking a $n a$-complement also in affirmative context.

In order to empirically investigate some contextual factors possibly having an impact on the choice of complement type with pistévo, an investigation was undertaken based on data from the HNC corpus. The main question posed was if negation in the matrix clause in some way contributes to the choice of subjunctive mood. According to the data collected this does not seem to be the case. The $n a$-complements were almost equally frequent in negated and non-negated contexts, showing that negation in itself cannot affect the mood choice. If the content of the complement is negated (by the negation of pistévo in the matrix clause), the non-commitment expressed by the subjunctive regards this negated content. In other words, the function of the subjunctive seems to be the same in negated as in non-negated context, and the choice of mood is not affected by the negation.

Apart from negation two other factors were examined, matrix verb in the first person singular of the present tense and complement with the predicate in the second person (singular and plural). None of the three factors examined in isolation turned out to be crucial for the choice of mood, but the combination of all three seems to be a context where a subjunctive complement is by far more frequent than an indicative one. With the complement predicate in the second person singular, the indicative is even rarer and did not occur at all in the corpus.

However, if the result of this investigation is representative, the particular pragmatic function of eliciting feedback (a context where an indicative complement seems to be impossible) seems to occur in negated context more frequently than in non-negated. Why this is so is an interesting question in need of further investigation, but it does not lead to the conclusion that the subjunctive is triggered by the existence of a negation in the matrix in a polarity-like manner. What triggers the subjunctive in these contexts, where this mood actually seems to be the only possible choice, is the pragmatic function of the utterance calling for the basic function of the subjunctive to express the subject's non-commitment to the truth of the complement.

\section{References}

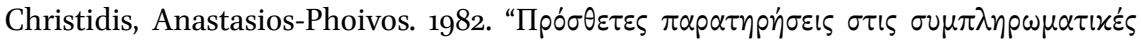

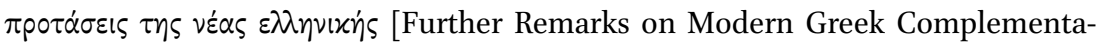
tion]." In Studies in Greek Linguistics 3, 47-72. Thessaloniki: Kyriakidi.

Farkas, Donka F. 1992. "On the Semantics of Subjunctive Complements." In Romance 
Languages and Modern Linguistic Theory, edited by Paul Hirschbühler and Konrad Koerner, 69-104. Amsterdam and Philadelphia: John Benjamins.

Giannakidou, Anastasia. 1994. "The Semantic Licensing of N PIS and the Modern Greek Subjunctive." In Language and Cognition (Yearbook of the Research Group for Theoretical and Experimental Linguistics) 4, 55-68. Groningen: University of Groningen.

Giannakidou, Anastasia. 1995. "Subjunctive, Habituality and Negative Polarity Items." In Proceedings of Semantics and Linguistic Theory $(S A L T)$ V, edited by Mandy Simons and Teresa Galloway, 94-112. Ithaca, NY: Cornell University.

Giannakidou, Anastasia. 1997. The Landscape of Polarity Items. Ph.D. dissertation, University of Groningen.

Giannakidou, Anastasia. 1998. Polarity Sensitivity as (Non)veridical Dependency. Amsterdam and Philadelphia: John Benjamins.

Giannakidou, Anastasia. 2000. "Crosslinguistic Semantics and the Study of Greek." Journal of Greek Linguistics 1:223-261.

Giannakidou, Anastasia. 2009. "The Dependency of the Subjunctive Revisited:Temporal Semantics and Polarity." Lingua 119:1883-1908.

Giannakidou, Anastasia. 2011. "(Non)veridicality and Mood Choice: Subjunctive, Polarity, and Time." In Tense across Languages, edited by Renate Musan and Monika Rathert, 59-89. Berlin and Boston: Walter de Gruyter.

Giannakidou, Anastasia, and Josep Quer. 1997. "Long-distance Licensing of Negative Indefinites." In Negation and Polarity: Syntax and Semantics, edited by Danielle Forget, Paul Hirschbühler, France Martineau, and María-Luisa Rivero. Vol. 155 of Amsterdam Studies in the Theory and History of Linguistic Science, 95-113. Amsterdam and Philadelphia:John Benjamins.

Holton, David, Peter Mackridge, and Irene Philippaki-Warburton. 1997. Greek: A Comprehensive Grammar of the Modern Language. London: Routledge.

Joseph, Brian D. and Irene Philippaki-Warburton. 1987. Modern Greek. London: Croom Helm Publishers.

Kakouriotis, Athanasios. 1982. "Complementation in Modern Greek and English." Papers and Studies in Contrastive Linguistics 14:99-127.

Philippaki-Warburton, Irene. 1994. "The Subjunctive Mood and the Syntactic Status of the Particle $n a$ in Modern Greek." Folia Linguistica 28 (3-4): 297-328.

Philippaki-Warburton, Irene, and Ioannis Veloudis. 1984. "The Subjunctive in Complement Clauses." In Studies in Greek Linguistics 5, 149-167. Thessaloniki: Kyriakidi.

Quer, Josep. 1998. Mood at the Interface. Ph.D. dissertation, University of Utrecht.

Quer, Josep. 2001. “Interpreting Mood." Probus 13:81-111.

Quer, Josep. 2009. "Twist of Mood: The Distribution and Interpretation of Indicative and Subjunctive." Lingua 119:1779-1787.

Roussou, Anna. 1996. "Subjunctive Complements in Modern Greek: A Preliminary 
Account." In UCL Working Papers in Linguistics 6, 259-286. London: University College London.

Roussou, Anna. 1999. "Modals and the Subjunctive." In Studies in Greek Syntax, edited by Artemis Alexiadou, Geoffrey Horrocks, and Melita Stavrou, 169-183. Dordrecht: Kluwer.

Roussou, Anna. 200o. "On the Left Periphery: Modal Particles and Complementisers." Journal of Greek Linguistics 1:65-94.

Roussou, Anna. 2009. "In the Mood for Control." Lingua 119:1811-1836.

Siegel, Laura. 2009. "Mood Selection in Romance and Balkan." Lingua 119:1859-1882.

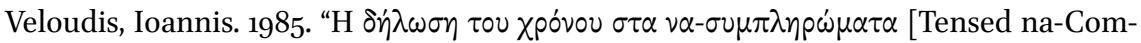
plements in Modern Greek]." In Studies in Greek Linguistics 6, 183-198. Thessaloniki: Kyriakidi. 